\title{
The Fall of the Bibliographic Wall: Libraries and Archives in Unified Germany
}

\section{Sem C. Sutter}

The end of the Cold War and the unification of Germany have inaugurated a new era in German library and archival history. Divided collections are being reunited, bodies of material considered lost after World War II are resurfacing in Eastern Europe as well as in Germany, and some archives heretofore closed are opening for the first time. Besides its inherent historical and political interest, the situation poses special challenges for the European administrators of the collections, as well as to American librarians assisting researchers who need to know about new resources. This article places recent developments in their historical context and summarizes information about collections whose status is likely to continue changing in the near term.

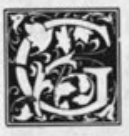

ermany, like no other country, came to epitomize the postwar division of Europe: severed into two states allied with the opposing political blocs, its largest city and erstwhile capital partitioned and eventually physically separated by the Wall that became the symbol of the Cold War. Germany as a land of books and readers experienced this rupture as well with the division of the national library, the national bibliography, the librarians' associations, several major publishing firms, and the national book fair. Therefore, as the Cold War ends, it is especially appropriate to look at German book and archival collections after the fall of the bibliographic wall. This article is a preliminary report based on early information that necessarily focuses on the initial developments and the most spectacular examples.

\section{ARCHIVAL AND MANUSCRIPT COLLECTIONS}

\section{Pre-World War II Archives}

The period since World War II has been difficult for researchers who wanted to consult German archival and manuscript collections. The dispersion and destruction of collections during the war, followed by the political division of Germany, often made it difficult to determine with certainty whether documents had survived and where they were housed, to say nothing of the potential difficulties of gaining scholarly access to them. While the passage of years saw the solution of a few mysteries and the easing of some restrictions, there was still a frustrating number of both by 1989. With the events of the last five years, however, some dispersed collections have begun to be reunited, restricted archives have become more accessible, and some manuscripts for- 
merly assumed destroyed have reappeared. The five collections described below offer some sense of the range of developments under way.

Preussisches Geheimes Staatsarchiv. The process of reuniting the Prussian State Archives (Geheimes Staatsarchiv) in their prewar location in the Dahlem section of Berlin began in April 1993 with the return of the first truckload of material from Merseburg in Saxony-Anhalt. These voluminous archives include Prussian administrative records, archives of the houses of Brandenburg-Prussia and Hohenzollern, and personal papers of prominent historical figures. Among them are some of the most important records of the Weimar period, although some documents seem to have disappeared and they may never resurface.

In 1943 German archivists moved the bulk of this collection to Saxony-Anhalt for safekeeping in salt and potassium mines, where Soviet occupying forces later confiscated it. Eventually the Soviets turned the material over to the government of Saxony-Anhalt and after 1950 the Interior Ministry of the German Democratic Republic (GDR) administered it in Merseburg as a division of the Zentrales Staatsarchiv. The 25,000 linear meters of material form a veritable archival mountain, dwarfing the 3,800 meters that remained in West Berlin, administered as the Geheimes Staatsarchiv Preussischer Kulturbesitz after the war. Archive officials estimate that it will require some one hundred truckloads to transport the material to Berlin over the course of a year. A converted granary will serve as an interim storage facility for several years, but the material will be available to researchers. ${ }^{1}$

Archives of the Deutsche Bank. The pre-1945 archives of the Deutsche Bank are an example of a private collection that has opened to researchers. The records of the bank are among the more important documents of German business history and, for the period of the Third Reich, among the most controversial. In May 1945 Soviet authorities entered the Deutsche Bank in Berlin and removed over 12,000 volumes of records from its vault. Eventually this material entered the Central States Archives (Zentrales Staatsarchiv) in Potsdam which contained primarily records of the old Reichsarchiv that were in Soviet-occupied territory at the war's end. (The rest of this Reichsarchiv material forms a part of the Federal Archives [Bundesarchiv] in Koblenz.) Since unification the archive in Potsdam has transferred the 12,000 volumes of records to the Deutsche Bank's own archive in Frankfurt while retaining a complete microfilm copy. Both the originals in Frankfurt and the microfilm in Potsdam are now accessible to researchers and typically five or six historians are using them at any given time. ${ }^{2}$

\section{Archive officials estimate that it will require some one hundred truckloads to transport the material to Berlin over the course of a year.}

Walther Rathenau Papers. An example of a manuscript collection believed lost in the 1930 s and 1940 s that has resurfaced since 1989 is the Nachlass (papers) of Walther Rathenau (18671922). Rathenau was the industrialist, intellectual, and statesman who helped put the German economy on a war footing during World War I and who, as minister of reconstruction and foreign minister after the war, negotiated the Treaty of Rapallo with the Soviet Union, breaking Germany's diplomatic isolation.

After Rathenau's assassination by right-wing extremists in 1922, his library and papers were maintained by the Rathenau Foundation in his former house in Berlin-Grunewald. When the Nazis came to power, the foundation dissolved and Rathenau's sister took the papers to Bavaria. When she fled Germany in 1939, the Gestapo confiscated twelve boxes of material. The editor of the 1985 English translation of Rathenau's notes and diaries based his edition on a condensed version published in 1930, noting that a complete edition would have been possible only if 
Rathenau's papers apparently had not been destroyed at the end of the war. He described in some detail his futile efforts to trace the papers, including visits to the Central State Archives of the GDR in Potsdam, the State Archive in Wroclaw, and the Warsaw Committee for Studies of Hitler's Crimes in Poland. ${ }^{3}$

\section{Often it is only by word of mouth that one learns where lesser-known collections are housed and who is in charge of them.}

In 1992, however, Rathenau scholar Wolfgang Michalka of Freiburg succeeded in discovering the papers miraculously complete and undamaged, some 70,000 pages in all, in the Central State Archive in Moscow where they had been inaccessible, even to Soviet researchers. Michalka learned that the papers had been sent to a castle near Breslau (now Wroclaw) for safekeeping, where the Soviet army captured them in September 1945. Highlights of the Rathenau papers were exhibited in January 1993 in the ReichspräsidentFriedrich-Ebert-Gedenkstätte in Heidelberg. Their discovery adds exciting new impetus to work on the complete edition of Rathenau's works, a project already under way. ${ }^{4}$

It is worth noting here that, while there are published modern catalogs of personal papers in Germany, former East Germany is relatively underrepresented in them and for some time to come researchers will be dependent on an oral tradition of scholarship. ${ }^{5}$ Often it is only by word of mouth that one learns where lesser-known collections are housed and who is in charge of them. ${ }^{6}$ For some time to come librarians may need to be prepared to help researchers look extensively and imaginatively for the locations of the manuscript sources they need.

Valuable documentation of music and the arts during the Weimar Republic has also been resurfacing in the East. For example, the archives of the Allgemeiner
Deutscher Musikverein have been unearthed in Weimar, and scattered materials pertaining to the Novembergruppe of artists and musicians and to the publications Anbruch and Melos are available in various libraries. ${ }^{7}$

\section{Archives created in the GDR}

Archives developed during the forty year history of the German Democratic Republic currently are opening to researchers who had no access to them before. Perhaps the most intriguing caches of material are two sizable media repositories.

Radio and Television Archives. At a press conference in January 1993 archivists from the Deutsches Rundfunkarchiv (Frankfurt) announced the upcoming opening of the archives of East German radio and television, to be housed in the library of the former GDR television network in Berlin-Adlershof. The historical and cultural value of material being made available, as well as its sheer volume, is phenomenal: 100,000 films; nearly 300,000 still photos; nearly 500,000 recordings of popular and classical music (including some 30,000 shellac discs from the Reichsrundfunk before 1945); 100,000 spoken recordings (including 23,000 radio plays); 2,500 linear meters of scripts and administrative archives. The list goes on and includes considerable material obtained through program exchanges with other socialist countries.

The German broadcasters' association (ARD, or Arbeitsgemeinschaft der öffentlich-rechtlichen Rundfunkanstalten der Bundesrepublik Deutschland), which sponsors the central radio archive in Frankfurt, has also underwritten the processing costs for this collection. Sorting and cataloging is about half complete and entries for the materials in Berlin are being added to a database at the Frankfurt archive. Catalogs of the material will eventually be published, but not until after processing is complete, perhaps at the end of 1994. The first cooperative project between the two archives is already under way-a union catalog of media material related 
to the persecution of Jews in Frankfurt and Berlin up to $1945 .{ }^{8}$

Film Archives. The movies produced by DEFA, the monopoly film company of the GDR, represent another important media archive becoming available for use. In March 1993 the University of Oldenburg Library paid 200,000 Marks for the 700 films in the archives of the DEFA studios in Potsdam. They include feature films, documentaries, and children's productions and represent about two-thirds of all films made in the GDR. The Library plans to recatalog the collection and make it available for research by historians, film scholars, and political scientists. Meanwhile, the only complete file of East German films, that of the state film archive, has been taken over by the Federal Archives in Koblenz. ${ }^{9}$

\section{LIBRARY COLLECTIONS}

Despite their complicated history and their still uncertain future, the story of German archives during the war seems almost simple when compared with the fate of library collections.

A wise bibliophile, lamenting the ordeals of books caught up in the vagaries of war, wrote:

Wars being without the control of reason make a wild assault on everything they come across and, lacking the check of reason, they push on without discretion or distinction to destroy the vessels of reason. ... For by wars [books] are scattered into foreign lands, are mutilated, wounded, and shamefully disfigured, are buried under the earth and overwhelmed in the sea, are devoured by the flames and destroyed by every kind of death. ${ }^{10}$

We might well imagine that the writer was a Polish scholar, a Russian librarian, or a Czech poet in the middle of the twentieth century. But, in fact, the author was Richard de Bury, writing in 1345 and quoted six hundred years later by the director of the University of Hamburg Library in his opening address to the first conference of librarians in the British Occupation Zone." Herrmann Tiemann's reference was poignantly apt, for the bibliographic depredations of
World War II in Eastern and Central Europe were comparable in spirit to the destruction of the library of Alexandria, while vastly exceeding it in scale.

\section{War-time Conditions}

Georg Leyh described German library buildings in 1945 as "ein riesiges Trümmerfeld," a vast expanse of rubble, but the damage to buildings and the books and catalogs in them is only a part of the story. As early as September of 1939 many libraries were moving their most precious books and manuscripts to their basements for greater security, but experience soon demonstrated that this was inadequate protection. By the fall of 1942 an unprecedented movement of books had begun as libraries evacuated millions of volumes throughout Germany in suitcases and packing crates, by truck, train, and coal barge. Books found temporary refuge in isolated castles and manors, in cloisters and churches, and especially in the depths of salt and potassium mines. The Deutsche Bücherei in Leipzig distributed 1.6 million volumes among ten locations, the Bayerische Staatsbibliothek more than a million in twenty-eight sites. At first books were carefully packed in tight containers and listed, but as conditions became increasingly frantic, librarians sometimes piled them up without any protection. It is hardly surprising that many books disappeared or were damaged in transit, that others fell prey to water and vermin while in storage, and that still others were plundered by individuals or by armies or occupying forces. Georg Leyh estimated total losses from German research libraries at 25 million volumesone-third of their 1939 holdings. ${ }^{12}$

1945-1989. In the years of postwar recovery, the majority of evacuated volumes found their way back to their libraries of origin or, as the Cold War set in, to two successor institutions. But many collections of books and manuscripts simply had vanished at the end of the war. Some eventually resurfaced in Poland and the Soviet Union, and a few of these were eventually returned to libraries in the GDR. For example, the 
autograph manuscript of Mozart's opera, Die Zauberflöte, and other valuable music manuscripts evacuated from the Preussische Staatsbibliothek were returned to the Deutsche Staatsbibliothek in East Berlin on the occasion of a Polish state visit in $1977 .{ }^{13}$ For the most part, however, pointed and repeated queries, especially from East German librarians to their Soviet counterparts and the Soviet government, fell on deaf ears.

\section{It is hardly surprising that many books disappeared or were damaged in transit, that others fell prey to water and vermin while in storage, and that still others were plundered by individuals or by armies or occupying forces.}

1989-1994. The events of 1989 and following have led to remarkable new developments in this area as well. Collections of library materials long given up as lost have been resurfacing. Through the combination of changed circumstances, institutions and governments in Western and Eastern Europe have found it possible and desirable to begin talking about returning materials to their libraries of origin. In a few cases collections have already been transferred, but it will require years of international cooperation to sort out many of the complex situations coming to light. Several examples will indicate the kinds of remarkable discoveries under way, some of the tangled issues surrounding them, and possible approaches to their resolution.

In the last several years the popular press understandably has devoted considerable attention to spectacular discoveries of caches of art-prints and drawings from Bremen and East Asian art from Berlin in the storerooms of the Hermitage, the treasures of King Priam of Troy hidden in the Pushkin Museum-and rumors of a German location for the fabulous Amber Chamber plundered from St. Petersburg.

Extraordinary discoveries of books and manuscripts also have occurred during the same period. For example, in 1942-43 the Staats- und Universitätsbibliothek Hamburg dispatched some 1,500 musical manuscripts and first editions of the seventeenth, eighteenth, and nineteenth centuries to a mine in Saxony for safekeeping. The collection included unique copies of operas and Singspiele composed for the Hamburg Opera. At the end of the war they disappeared, and as time passed they were considered destroyed or lost forever. In 1990 a German musicologist discovered them by chance in St. Petersburg, stored in the Russian Institute of Art Studies. Although stamped by Soviet military officials in 1945, they had never been processed. After negotiations between city governments (Hamburg and St. Petersburg happen to be partner cities), the collection was returned to Hamburg in exchange for a gift of 150,000 Marks. ${ }^{14}$

\section{Russian National Library}

Unfortunately, not all of the discoveries to date have enjoyed such swift resolution. According to published reports, the Russian National Library (formerly Saltykov-Schedrin Public Library) in St. Petersburg holds an estimated 340,000 German books brought there by Soviet troops at the end of the war from storage sites where libraries in Hamburg, Bremen, Lübeck, Leipzig, and Magdeburg had placed them for safekeeping. Deputy Director Elena Nebogatikova reports that she was the first member of the library's staff to pay any attention to the books since their arrival in 1946-47. In December 1991 she had the disorganized collections moved from large store rooms in the library's closed stacks to a former bookstore building in the city where a team of catalogers began taking inventory. The books seem to run the gamut from incunabula and sixteenthcentury imprints to scholarly monographs and serials of the 1930s. Ms. Nebogatikova sees the inventory as a first step toward deciding the books' future, but she is skeptical about the prospect of their return to Germany, pointing out that the severe cultural losses that German troops inflicted on the Soviet 
Union demand an exchange of equal value. She also notes that she has received offers from German book dealers to purchase the books. ${ }^{15}$

This is not an isolated situation. In 1992 a staff member of the Russian Ministry of Culture told a reporter for Der Spiegel that so-called trophy literature from Germany was stored in over fifty locations, some as far east as Tomsk. The reporter visited the Tomsk University $\mathrm{Li}$ brary where the director displayed several thousand volumes from Magdeburg, Bremen, and Berlin, lamenting that no one there could read the Gothic script. He said that a rare book dealer from Berlin had offered to buy some of the eighteenth-century science and topography titles, but unfortunately he had not heard from the gentleman again. ${ }^{16}$

\section{Given the strong feelings about the Second World War as well as the economic circumstances of libraries in the former Soviet Union, it is perfectly understandable why librarians might consider selling books that are useless to the vast majority of their readers.}

Is the antiquarian market the most likely venue by which such books are likely to return to Germany? Given the strong feelings about the Second World War as well as the economic circumstances of libraries in the former Soviet Union, it is perfectly understandable why librarians might consider selling books that are useless to the vast majority of their readers. But in the GermanSoviet treaty signed in 1990 both nations agreed "that lost or unlawfully transferred art treasures which are located in their territory will be returned to their owners or their successors. ${ }^{17}$ How all of the parties involved can work through this complex set of problems in practical terms remains to be seen. There is a broad range of opinions among librarians, and a lively discussion is under way among them about the wisest and most equitable course to pursue.

\section{The Church at Uzkoye}

Much of this dialogue revolves around the most spectacular discovery of books to date, a cache in the Church of St. Anne at Uzkoye just outside Moscow, variously estimated to contain hundreds of thousands, or "over a million," or even as many as 1.5 million volumes. ${ }^{18}$ Journalist Evgeny Kuzmin first publicized the discovery in an article in Literaturnaya Gazeta in the fall of 1990 . He described German books intermingled with Russian volumes withdrawn from circulation under Stalin and stacked from floor to ceiling, all jammed in so tightly that those at the bottom had crumbled. He called it "a kind of Katyn massacre, except that dumped into an unknown common grave are not people, but books."19

In the months that followed Kuzmin's call for action, a round table of librarians convened at the National State Library of Foreign Literature in Moscow to discuss the "trophy literature" in the hope of reaching a consensus and assisting the government in resolving the problem. A wide range of experiences and opinions emerged that I can only summarize here briefly. ${ }^{20}$

The former head of the manuscripts division of the Russian State Library (formerly the Lenin Library), S. V. Zhitomirskaíà, described vividly the emotions she and her colleagues felt in 1946 as they surveyed the captured books and manuscripts to choose materials for their library. There was a feeling of euphoria and triumph that astonishes her today. But as they began working concretely with manuscripts from Berlin, Dresden, Gdansk, and the Polish National Library they found themselves increasingly uneasy about the appropriateness, indeed the morality, of holding medieval codices, seventeenth-century archival records, and the personal papers of great German cultural figures-Fichte, Chamisso, and others. "It's as if the manuscripts of Tolstoy or Dostoyevsky lay in Berlin!" she exclaimed. Their misgivings grew as queries began to come from libraries in 
the GDR, a fellow socialist country. But no one even asked about the ethical qualms of librarians-officials at the highest levels decreed that the holdings be kept secret and librarians swallowed their reservations.

Eventually, beginning in 1957, most of the manuscripts at the Lenin Library were restored to the GDR and to Poland, but a great many books remain. Ms. Zhitomirskaía and other round table participants pointed out that many of these books have been integrated into their libraries' collections and ferreting them all out today would be difficult, if not impossible. Why not, she suggested, ask German librarians to prepare lists of the missing books that they actually still want back? Once desiderata lists are in hand, let us make every effort to find these books and return them.

The Germans promised to pursue research in the West about the whereabouts of books removed from the Soviet Union during the war.

While some librarians at the round table advocated returning all books to the libraries of origin without delay, others argued that at this late date the question of return or nonreturn is irrelevant. Instead, librarians in the former Soviet Union as well as in Germany should concentrate on making holdings known and truly accessible to researchers across borders. This would strengthen bonds of international scholarly cooperation. Between these two ends of the spectrum lay several other opinions: (1) let us return all of the trophy literature without delay and without condition, but it is reasonable for the Germans as a fitting gesture of goodwill to supply our major libraries with their new publications for several decades; (2) the books should return to their home, whether by exchange or sale, realizing that for some of the old and rare books an equivalent trade may not be possible; (3) the many warehoused books that have never been processed certainly should be returned, but perhaps for those that were cataloged over the years the only practical course is to assure that they are accessible to researchers of all nations.

Although the librarians did not achieve unity of opinion, they were able to agree on several practical measures. They recommended formation of a commission of knowledgeable librarians, scholars, lawyers, and economists to study the problem in greater detail. In order to support the work of this commission, they formulated a questionnaire for distribution to all libraries, soliciting concrete data about their holdings of captured books as well as about their own wartime losses.

\section{NEGOTIATIONS}

Meanwhile, negotiations have begun on several fronts in the spirit of the 1990 "Treaty on Good-Neighborliness, Partnership, and Co-operation." In December 1992 a delegation of German librarians and public officials met with forty of their counterparts in Moscow just before Chancellor Kohl's state visit. Evgeny Kuzmin, now an official responsible for library affairs in the Russian Ministry of Culture, showed the group documents recently uncovered in archives of the Defense Ministry and the Communist Party Central Committee that detail as never before the removal of books and art objects from Germany in 1945 and their dispersal. Despite differences of opinion, participants in the discussions seemed to realize that the historical complexities dictate that there can be no comprehensive resolution for all of the cultural properties displaced during the war, that insistence on narrow legal definitions is unlikely to be productive, and that all parties will need to be sensitive to one another's special concerns and circumstances.

The discussions seem to have generated real progress, indicating some of the elements that may make possible eventual resolution of some problems. Both sides agreed to make information freely available to one another's experts and to deter commercial trade in these books. The Germans promised to pursue 
research in the West about the whereabouts of books removed from the Soviet Union during the war. Particularly encouraging is the fact that at least three pilot projects between individual institutions began in 1993. In exchange for returning books to Germany, the pilot libraries will be receiving copies of the books, new German books and serial subscriptions, assistance equipping reading rooms, or technical aid for preservation programs. ${ }^{21}$ The degree of success of these first endeavors will surely affect future action.

\section{CONCLUSIONS}

Clearly, major changes are under way in German libraries and archives since unification. Dispersed collections have begun to be reunited, some restricted archives have become more accessible, and some resources that were assumed to have been destroyed have resurfaced. In some instances the change has been swift and it will take time until it is well documented. Other situations are so complicated that they will require years to sort out. Under these circumstances, librarians and researchers on both sides of the Atlantic will need to depend upon word of mouth and upon one another to locate resources. Sources for this information may include news reports in the German national press (Die Zeit and Der Spiegel, for example) and in NEXIS, articles and announcements in scholarly journals and the German library press, mention in electronic discussion groups, or information in the rapidly developing Gopher sites in Germany.

\section{REFERENCES AND NOTES}

1. "Return of Former Prussian State Archives from Merseburg to Berlin Begins," The Week in Germany (New York), Apr. 16, 1993, 6.

2. Jessica Gienow, "Die Deutsche Bank stellt sich ihrer Geschichte," Süddeutsche Zeitung (Munich), Dec. 24, 1992.

3. Walther Rathenau, Industrialist, Banker, Intellectual, and Politician: Notes and Diaries 19071922, ed. Hartmut Pogge von Strandmann (Oxford: Clarendon, 1985), xi-xii.

4. Ernst Schulin, "Rathenau in Moskau: Zur Wiederauffindung seines Nachlasses," Frankfurter Allgemeine Zeitung, Sept. 29, 1992; Wolfgang Michalka, "Rathenaus Nachlaß in Moskau entdeckt," Das Parlament (Bonn), Oct. 2, 1992; "Rathenau-Nachlass in Heidelberg ausgestellt," Süddeutsche Zeitung (Munich), Jan. 14, 1993.

5. Wolfgang A. Mommsen, Die Nachlässe in den deutschen Archiven, 2 vols. (Boppard am Rhein: H. Boldt, 1971-83); Ludwig Denecke, Die Nachlässe in den Bibliotheken der Bundesrepublik Deutschland, 2d ed. (Boppard am Rhein: H. Boldt, 1981); and Ingrid Kussmaul, Die Nachlässe und Sammlungen des Deutschen Literaturarchivs Marbach am Neckar: Ein Verzeichnis (Marbach am Neckar: Deutsche Schillergesellschaft, 1983).

6. Tamara Levitz, "Archival Research in Former East Germany," Kurt Weill Newsletter 9 (Fall 1991): 8.

7. Ibid., 9.

8. Peter Paul Kubitz, "Die Hinterlassenschaften der Sammelwut in der Ex-DDR," Süddeutsche Zeitung (Munich), Jan. 15, 1993.

9. "Universität Oldenburg kauft DEFA-Archiv," Süddeutsche Zeitung (Munich), Mar. 18, 1993.

10. Richard de Bury, Philobiblon, tr. E. C. Thomas (Oxford: Shakespeare Head Pr., 1960), 71, 77.

11. Hermann Tiemann, "Vom Sein des Buches," in Probleme des Wiederaufbaus im wissenschaftlichen Bibliothekswesen: Aus den Verhandlungen der 1. Bibliothekartagung der britischen Zone in Hamburg vom 22.-24. Oktober 1946 (Hamburg: Hansischer Gildenverlag, 1947), 14.

12. Georg Leyh, Die deutschen wissenschaftlichen Bibliotheken nach dem Krieg (Tübingen: Verlag von J. C. B. Mohr, 1947), 9-11. See also his description of the war years in Handbuch der Bibliothekswissenschaft, vol. 3, pt. 2 (Wiesbaden: Otto Harrassowitz, 1952-61), 473-91.

13. For a popular account of this story that reads like a thriller, see Nigel Lewis, Paperchase: Mozart, Beethoven, Bach ... The Search for Their Lost Music (London: Hamish Hamilton, 1981). See also Dieter Henrich, "Beethoven, Hegel und Mozart auf der Reise nach Krakau," Neue Rundschau 88 (1977): 165-99. 
14. Details provided in letters from Bibliotheksdirector Herbert Blackert, Staats- und Universitätsbibliothek Hamburg, May 11 and 12, 1993.

15. Mathias Brüggmann, "Der Schatz an der Newa" and "Vergangenheit, vom Staub befreit," Hamburger Abendblatt, June 13, 1992, 10.

16. “Letzte Geiseln," Der Spiegel 46 (Mar. 9, 1992): 212, 215, 218.

17. Article 16 of "Treaty between the Federal Republic of Germany and the Union of Soviet Socialist Republics on Good-Neighborliness, Partnership, and Co-operation, signed in Moscow, Nov. 9, 1990," transl. in Jonathan Osmond, German Reunification: A Reference Guide and Commentary (Harlow: Longman Current Affairs, 1992), 295.

18. "Letzte Geiseln," 215; The German Tribune (Hamburg), May 8, 1992, 10.

19. As quoted by Helen Womack, "Old Masters Unearthed in the Soviet Union," Independent (London), Apr. 28, 1991, 13.

20. A summary of the meeting appeared in Bibliotekar, no. 7 (1991): 15-18 and in German translation as "Rückkehr aus Gefangenschaft," Bibliotheksdienst 25 (June 1991): 842-53.

21. Kerstin Holm, "Keine taube Ohren," Frankfurter Allgemeine Zeitung, Dec. 15, 1992; "Durchbruch in Moskau," Hamburger Abendblatt, Dec. 16, 1992; letters from Elisabeth Simon, Geschäftsführerin, Deutsches Bibliotheksinstitut, Bibliothekarische Auslandsstelle, Apr. 16 and 22, 1993, and Peter Borchardt, Deutsches Bibliotheksinstitut, Bibliothekarische Auslandsstelle, May 21, 1993.

\section{Nota Bene}

Jay Martin Poole, a member of the Editorial Board, director of the Fogelson Library at the College of Santa Fe, and a former editor of CHOICE magazine, died suddenly on July 21, 1994. His many contributions to librarianship and to the production of College \& Research Libraries will be profoundly missed. The talents he developed in others endure. 

ALL LIBRARIANS

\section{THE MYTH OF THE \\ ELECTRONIC LIBRARY \\ Librarianship and Social Change \\ in America \\ By William F. Birdsall}

Critically challenges the prevailing view that the electronic library represents the only secure future for librarians.

Greenwood Press. 1994. 216 pages.

0-313-29210-8. \$55.00

\section{MULTICULTURALISM IN LIBRARIES}

By Rosemary Ruhig Du Mont, Lois Buttlar, and William Caynon

Examines the role of libraries in a multicultural society and explores how libraries can meet the needs of multicultural populations.

Greenwood Press. 1994. 256 pages.

0-313-28418-0. $\$ 55.00$

\section{THE CHALLENGE AND PRACTICE OF ACADEMIC ACCREDITATION \\ A Sourcebook for \\ Library Administrators \\ Edited by Edward D. Garten}

Summarizes current accreditation agency guidelines for academic libraries and information technologies and discusses challenges and issues in this area.

Greenwood Press. 1994. 312 pages.

0-313-28897-6. \$65.00

\section{VIDEO COLLECTION \\ DEVELOPMENT IN \\ MULTI-TYPE LIBRARIES \\ A Handbook \\ Edited by Gary P. Handman}

Provides detailed information on developing video collections in different types of libraries, the nature of the video market, and approaches for selecting materials.

Greenwood Press. 1994. 496 pages.

0-313-27902-0. $\$ 75.00$

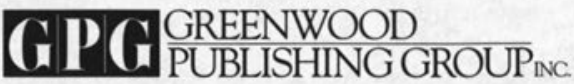

\section{RECRUITING, EDUCATING, AND TRAINING LIBRARIANS FOR COLLECTION DEVELOPMENT}

Edited by Peggy Johnson and Sheila S. Intner

Addresses three significant problems experienced by library administrators around the country: attracting new collection development librarians, educating them in appropriate library school programs, and training them to perform their jobs.

Greenwood Press. 1994. 264 pages.

0-313-28561-6. \$55.00

\section{ASPIRATIONS AND MENTORING IN AN ACADEMIC ENVIRONMENT Women Faculty in Library and Information Science}

By Mary Niles Maack and Joanne Passet

The first book to focus on the aspirations and career development of female library-school faculty as well as a thorough review of obstacles and the importance of the mentoring process.

Greenwood Press. 1994. 232 pages.

0-313-27836-9. \$49.95

\section{ACADEMIC LIBRARIES}

\section{The Dimensions of Their Effectiveness}

By Joseph A. McDonald and

Lynda Basney Micikas

Based on a significant empirical investigation, this book argues that the success of isolated activities is not a reliable guide to academic library effectiveness.

Greenwood Press. 1994. 208 pages.

0-313-27269-7. \$49.95

\section{LIBRARY RECORDS}

\section{A Retention and Confidentiality Guide}

By Shirley A. Wiegand

Overviews state laws regarding the retention and confidentiality of library records, and shows why librarians must recognize that library records are subject to public record retention laws.

Greenwood Press. 1994. 256 pages.

0-313-28408-3. \$59.95

88 Post Road West, Box 5007, Westport, CT 06881 (203) 226-3571 • Fax (203) 222-1502

Please call or fax us for our latest catalogs! 